\title{
The Implementation of Islamic Heritage Law
}

\author{
Waluyadi Waluyadi* \\ Faculty of Laws \\ Universitas Swadaya Gunung Jati Cirebon \\ Cirebon, Indonesia \\ *waluyadi01@gmail.com
}

\author{
Setia Budiyanti \\ Faculty of Teaching and Educational Science \\ Universitas Swadaya Gunung Jati Cirebon \\ Cirebon, Indonesia \\ budiyantisetia@gmail.com
}

\begin{abstract}
The purpose of this study is to describe and analyse the implementation of Islamic inheritance law in Cirebon. The doctrinal research approach and qualitative research specifications are applied using primary and secondary data. The study used literature study and conducted interview to some people to collect the data. Data were analysed using prescriptive analysis. The results showed that the implementation of the distribution of the inheritance among people in Cirebon are still far from Islamic Law.
\end{abstract}

Keywords: Islamic Law, inheritance

\section{INTRODUCTION}

Indonesia adheres to a mixed legal system that lives side by side. Islamic inheritance law only applies to Muslims. For external matters it is subject to the law that binds the group. Eliana Carranza [1] stated that "Indonesia has a mixed legal system in which Islamic law exists with Western civil law. The jurisdiction of Islamic legislation includes only cases of Muslim family law. Instead civil legislation regulates different aspects of economic, political and social activity for all population group'. According to Andi Asdar Yusup [2]. Inheritance from the people of different religions is the practice of dividing inheritance involving two or more persons of different faiths between one Muslim and another non-Muslim either as testator or heir. Inheritance from the people of different religions is very complicated practice in modern times, especially when those who are entitled to inheritance are Muslim from non-Muslim parents or relatives, as the case in some places in Indonesia.

Ideally a person or group of people who have pledged themselves and are subject to Islamic law, then the inheritance law must be binding on him. Siti Fatimah Abdul Rahman and friends [3] stated. The awareness about Islamic Inheritance Law (Faraid) is very important among Muslims in order to be fair when distributing the property of the dead to the heirs. Faraid is used as a way to distribute one's property based on the reference from the Qur'an and As-Sunnah.

According to Afidah Wahyuni [4], the style of an Islamic state and life in that country or region have a different influence on inheritance law, this is caused by: First, even though Islam has regulated in detail about inheritance. If there is an understanding has been explained by the Prophet. However, in terms of practical implementation contained in the Al-Quran and not yet been explained by the Prophet, so the law becomes open. Second, that jurisprudence includes Islamic law, in which inheritance law is classified as social science and not exact science. Therefore, inheritance law has the possibility of differences of opinion among the legal experts themselves, especially regarding the verses that allow the interpretation of more than one.

Results of the research on the implementation of Islamic inheritance law in Kepuh Village, Palimanan District, Cirebon Regency in 2017 [5] of them is known that the distribution of inheritance in the village is carried out evenly for all heirs. This division is known as 'the meaning of harmony'.

The question arose is what about other villages or villages in other regions that are still in Cirebon? The purpose of this research is to describe and analyse the implementation of Islamic inheritance law in Cirebon. The results of this study are practical and can be used as a guideline for the Cirebon city or regency government in developing policies in the religious field.

\section{MEthodology}

The focus of this research is the implementation of Islamic inheritance law for Muslims in Cirebon. The approach in this study is doctrinal / normative and qualitative research specifications. The data used are secondary and primary data. Secondary data obtained by library research and primary data obtained by interview. Interviews with respondents in 45 villages in Cirebon city and district. For each village, there are 1 to 20 respondents. Respondents are religious leaders and community leaders. The data collected was analysed prescriptive.

\section{RESULTS AND DiSCUSSION}

\section{A. Distribution of Inheritance is Done Evenly, to Avoid Conflict}

Findings on: the distribution of inheritance evenly based on fears of conflict, when using Islamic inheritance law, needs to be straightened out sharply. Hendra Hudaya [6] asserted, the practice of Islamic inheritance law would actually keep away from family conflicts. This opinion is based on the hadith of the Prophet: Ibn Mas'ud r.a. said that the Prophet Muhammad SAW said 'Learn the Qur'an and teach it to people. And study the science of Faraidh and teach it to people because I am a person who will be taken away (dead), while that science will be raised and slander will be seen, so that two people who fight 
about the distribution of inheritance, they both do not find anyone capable of resolving (resolving disputes) division of inheritance rights)".

\section{B. Distribution of Inheritance is Done through Discussion}

Article 183 Presidential Instruction of the Republic of Indonesia Number 1 of 1991 concerning Compilation of Islamic Law confirms that heirs can agree to make peace in the distribution of inheritance, after each of them is aware of its share. Ahmad Azhar Basyir [7] states, in Islamic inheritance law it is possible tashaluh (peace) or takharuj regarding the distribution of inheritance. If the peace is carried out precisely because they are not satisfied with the provisions of Islamic inheritance law, for example which determines that the male portion is equal to for two women, such peace reflects precisely the lack of sincerity in judging the provisions of Allah and His Messenger.

\section{Distribution of Assets is Considered When the Heir is Still Alive, is Considered an Inheritance.}

Ahmad Zahro [8] provides a definition of Wiratsah / inheritance as a transfer of ownership from a deceased owner to a living recipient due to inheritance rights. Referring to this definition, the giving of assets before the owner dies cannot be called an inheritance. According to him, the property may be divided when the owner is still alive, even this method is relatively better because the potential for conflict is smaller, but the names and conditions are not names and conditions of inheritance, but a grant made by the owner of the property to those who later become heirs. According to Ahmad Azhar Basyir grants to the right to inheritance at the time of the heir's life are not seen as inheritance. However, according to him, if there is a parent giving something to one of their children, even though there is a lot of delinquency, Islamic teachings about being obliged to do justice in giving grants to children can be considered whether other children should also be given grants taken from inheritance.

\section{There Are Adopted Children Who Get Inheritance}

In this case Ahmad Zahro notes:

- The Messenger of Allah had adopted a child from Harithah named Zaid who then exchanged the child's call from Zaid bin Harithah to Zaid bin Muhammad, which means that Zaid had a relationship with the Prophet;

- After the verse of Al-Qur'an came down, the Surah AlAhzaab verses (4) and (5) Zaid was resubmitted to his parents, namely Zaid bin Harithh;
- $\quad$ Referring to Al-Qur'an, Al-Ahzaab verses (4) and (5) that adopting a child by transferring the text which results in kinship and legal inheritance is prohibited (haram);

- The forbidden status, in addition to the fact that Allah SWT forbade what had been done by the Messenger of Allah and the Apostle to accept it, was also based on consideration; to avoid disrupting family relations and their rights; to avoid the possibility of misunderstanding between the halal and the haram (in the case of mahram and aurat); to avoid the possibility of hostility between nasab and adopted children (in the case of inheritance); to secure the creed (if adoptive parents are non-Muslim) and to uphold justice;

- $\quad$ So in the perspective of Fiqh (Islamic law) it is clear that adopted children do not get inheritance rights from adoptive parents.

\section{CONCLUSION}

Normative distribution of inheritance does not refer to Islamic law, as all heirs receive equal shares. Distribution of inheritance is also done by peace. The giving of parents' assets to children is counted as inheritance. The adopted child gets an inheritance.

\section{REFERENCES}

[1] E. Carranza, Islamic inheritance law, son preference and fertility behavior of Muslim couples in Indonesia, The World Bank, 2012

[2] A.A. Yusuf, "Controversy of Islamic Law on The Distribution of Inheritance to the Heirs of Different Religion," HUNAFA: Jurnal Studia Islamika, vol. 14, no. 2, pp. 377-403, 2017

[3] S.F.A. Rahman, A.M. Yaakob, A.A. Fadzil, and M.F. Shaban, Asse Distribution Among The Qualified Heirs Based on Islamic Inheritance Law, December, 2017.

[4] A. Wahyuni, "Sistem Waris dalam Perspektif Islam dan Peraturan Perundang-Undangan di Indonesia," SALAM: Jurnal Sosial dan Budaya Syar-i, vol. 5, no. 2, pp. 147-160, 2018.

[5] M. Hazim, Pemberlakukan Hukum Waris Islam di Desa Kepuh Kecamatan Palimanan, Kabupaten Cirebon (Skripsi), Cirebon: Universitas Swadaya Gunung Jati, 2018.

[6] H. Hudaya, Fiqih Waris, Mudah dan Praktis, Jakarta: Gema Insani, 2018

[7] A.A. Basyir, Hukum Waris Islam, Edsi Revisi, Yogyakarta: UII Pres, 2009.

[8] A. Zahro, Buku I FIQIH KOnteporer, Menjawab 111 Masalah Hukum Islam di Zaman Kita, Qaf Media Krativa, Cetakan I, 2018. 